\title{
Seasonality and Poverty: Implications for Policy and Research
}

\author{
Richard Longhurst, Robert Chambers and Jeremy Swift
}

\section{Approaches to Seasonality}

The papers in this Bulletin illustrate how acute the seasonal stresses placed on poor rural people can be, and how much they differ between groups and environments. Diverse groups such as pastoralists, culivators, the landless and women have different repertoires of response to cope with regular seasonal stresses, and use them with varying degrees of success. They find it harder to deal with unexpected fluctuations in food supply or incomes, or sudden losses of livelihood or family member, as can occur through unanticipated domestic or economic events. For regular seasonal stresses, coping mechanisms are many and include depleting food stocks, eating less, changing the composition of the diet, migration, exploiting common property resources, switching occupations, selling assets such as livestock, and changing cropping patterns and farm operation. These strategies are often versatile and complex and little understood by outsiders. The most striking aspect of how people cope with seasonality is its diversity. There are agronomic, nutritional, economic, demographic and social mechanisms which are called into play, and the human body itself also has a range of biological adaptations in the face of stress.

These articles and other research in the past few years qualify and refine the original wet-dry seasonal scenario [see Chambers, Longhurst and Pacey, 1981]. Four aspects stand. The first is the significance of quite short recurrent periods during the year, often a matter of a few weeks and sometimes just a few days. Examples are transplanting rice among Lambardi and Koya tribals in India, when women are overworked, children neglected and births peak; planting, weeding and harvesting peaks with some crops especially in unimodal short rainy season agriculture; and the transitional period from dry seasons to rains when pastoralists' workloads are intense, cereal prices high and herds vulnerable.

Second, the inter-seasonal effects of a succession of bad years can swamp the 'normal' seasonal pattern.
The build-up to the 1984/85 famine in Eastern Africa and the Sahel was preceded by several years of poor rainfall during which rural people's sequence of coping mechanisms described in several articles in this Bulletin were brought into play and progressively weakened. Selling assets became less effective as prices, for instance for livestock, fell dramatically. In Ethiopia, cereal prices continued to rise after harvest when the normal seasonal effect would have been for them to fall [Cutler 1985]. Similarly, after a succession of bad years migration will not follow normal seasonal patterns.

For some, contingencies may overlap with the combination of seasonal and household life cycle stress. People in the households are especially vulnerable. These households include those with several small children, or composed of old people, or having to cope with a major life cycle event such as overcoming death of a productive member or meeting the expenses of a marriage.

Third, different groups, especially children, women and men experience and perceive the seasons differently. Stress is 'handed on' from men to women and children, as vividly illustrated in the paper by Jiggins. For the Indian tribals studied by Gillespie (1986), July transplanting was perceived as bad by women, and winter guarding of crops as bad by men. There are similar differences between large farmers, subsistence farmers, and the landless. Grain deficit households search for food while surplus households accumulate wealth. In Mali, as elsewhere, differences in asset ownership enabling some Bambara, at the expense of others, to diversify income earning activities.

Fourth, seasonality can be a major dimension of adverse economic change. In sub-Africa, in particular, it is part of the process of impoverishment which is making people more vulnerable. Increasing population, scarcer land, changes in resource ownership and access and declining land quality together amplify 
seasonal fluctuations and shortages of both food supply and agricultural incomes. The pastoralists of Central Niger are probably typical of many others in losing land to agriculturalists, being increasingly forced to sell off their young cattle and herd cattle owned by non-pastoralists for low wages, and holding herds whose numbers and composition are no longer viable. As they and others lose assets and become poorer, they become less and less able to cope with bad years and also more vulnerable to regular seasonal stress.

For these four reasons, seasonal analyses and counterseasonal measures have to be more sensitive and more differentiated - in timing, within seasons, in response to previous bad years, in helping vulnerable groups, and in slowing and counteracting impoverishment. With deepening poverty, seasonality also becomes even more significant as an adverse factor, and as a point of entry for analysis and action. It is of especial relevance to sub-Saharan Africa with its long-term decline in per capita agricultural production, directly and distressingly linked to poverty and development. It is important not just to enable people to struggle out of poverty, but through various measures to strengthen and add to their coping mechanisms so that their vulnerability does not increase. Seasonality, even more than before, is a critical dimension in rural programmes. Counter-seasonal interventions can moderate adverse seasonal effects, but the best seasonproofing is not to be poor, and the best counterseasonal policy is one which successfully targets resources to enable those who are vulnerable to become less poor.

\section{Implications for Policy}

Seasonality needs to be keyed into existing policy, technology development, and support for vulnerable groups. It needs to be repeated that poverty and seasonality are interlinked and that without poverty there would be fewer, or no, adverse seasonal effects.

Regarding general policy, three points can be made. First, seasonality-related policies should seek to strengthen and add to - not weaken - the many ways in which people cope with seasonal stress and reover from it.

Second, analysis and action have to be decentralised and differentiated, in timing and targetting: seasonalities vary, and include short crucial periods, local environmental diversity, especially in hinterlands away from more uniform and developed agricultural areas of deltas and plains, and differential vulnerability and impacts for children, women and men. These all require a versatile repertoire of possible counterseasonal interventions; blanket measures applied widely are unlikely to be very effective. Third, it is crucially important that awareness is increased: that urban-based, season-proofed professionals become more aware of what rural people know only too well about how adverse seasonality affects them and how they try to handle it. Far greater knowledge and appreciation is required of the pattern of income earning and food acquiring activities of vulnerable people, especially when urban-based professionals are least likely to travel at the times of year when things are worst for rural people.

In the area of agricultural research and technology development, it is basic to recognise the complex measures adopted by farmers to exploit the seasons while moderating risk. Crop diversification, mixed cropping and serial cropping are all means whereby farmers cope with uncertain rainfall. Different varieties within a crop allow staggered dates of harvesting to provide a flow of harvested material and income over an extended period and spread risks and smooth labour peaks. Agricultural technologies that allow people greater choice of activity and timing should be considered. In the context of seasonality in sub-Saharan Africa this requires giving more support to crops which can be harvested flexibly, such as root crops and some gathered foods, and to those varieties of cereals and legumes that are counter-seasonal in impact. For example, development of quick-maturing millets would reduce risks in drought-prone areas and shorten the hungry season. The seasonal perspective in agricultural research adds support to two criteria in agricultural research: yield per unit time in addition to per unit area; and the timing of activities and especially harvest in relation to household resources and needs. Emphasis on livestock such as cattle and sheep, which in the Sahel provide milk in the rainy season when farmers' food stocks are low, can be important for the same reason, while camels and goats may play a similar role for herders in their hungry dry season.

Seasonal stress is often most critical for groups who are vulnerable anyway. These are the poor and those at vulnerable stages in the household life cycle, and within the poor, women and children. For the poor, this indicates allocation of agricultural research resources for the crops they grow. For women and children, linkages can be made between the allocation of a woman's time, her welfare and that of her child.

Technology in the domestic domain (processing, preservation and preparation) could well ease seasonal work bottlenecks for women. Technology in agriculture can have an important impact on vulnerable group health by spreading work peaks or increasing returns to women's crops and livestock and their income. In most countries there is a complex 
sexual division of labour and appropriation of product from farm work. Women do have activities, the products of which both contribute to the communal cooking pot and to their own incomes. The latter in particular can have a significant impact on child nutrition, especially seasonally when malnutrition is worst. A direct seasonal intervention as discussed in the Editorial, would be provision of child care facilities even for a short period, when women are working in the fields in the rainy season. This should improve both child health and agricultural productivity: a linkage which illustrates the value of a seasonal mode of analysis.

The more strictly economic domain offers several means of mitigating adverse seasonal effects. One is a better integration of markets. In sub-Saharan Africa where market integration is poor, this is especially important. There is scope for improved roads and other physical infrastructure, and better information and communication for the more accurate prediction of prices for foodgrains and livestock. Another measure, of benefit to the landless and pastoralists, is price stabilisation of foodgrains at reasonable low levels during the dry season and early wet season. Yet another is official intervention in the livest ock market when bad conditions threaten a slump, to maintain livestock values and the livestock to grain exchange ratio. Again, if other assets or products are sold, such as firewood or charcoal, these can be bought and stockpiled, with the advantage that they may store better than livestock, and do not deplete herds. (Credit schemes need reassessment together with extension, to make marketing chains less risky, especially for livestock). Recovery from a bad season also deserves imaginative support, and loans for the replacement of major capital assets such as cattle would enable pastoralists to recover more quickly. There is probably a major role for financial intermediation through more flexible and widespread credit schemes and possibly banking, especially for those pastoralists whose economy is more market integrated. Grain stores and cereal banks, facilitated by targetted credit, could also be important for both farmers and herders.

Seasonal fluctuations in food availability are often seen to be most marked in drought prone or semi-arid areas. In periods of acute famine, families turn to the bush for foods and livelihoods. A natural resources policy to protect common property resources, especially trees, is essential. Trees act as important seasonal buffers, as shown in this Bulletin, providing food, forage for livestock, firewood charcoal, medicines, and other products. All of these can be converted into scarce seasonal income for those who own or have access to the trees. Pilot and experimental tree fodder projects by and with pastoralists (including trials with tenure and insufruct arrangements) deserve to be undertaken. Seasonal grazing and browse reserves may also have a role to play as long as they ar genuinely under the control of the local community.

The occurrence of acute seasonal food shortages turning into a famine before effective relief measures can be taken might be avoided by decentralised diagnosis. This will require the identification of appropriate indicators and the establishment of a household or village level response mechanism. As indicators, Campbell and Trechter (1982) have suggested hunting and gathering of wild foods, and migration, as being relatively easier to monitor with eating behaviour of households less easy to judge. Unexpected price rises and drying out of river beds might be easy to monitor. Generally the head people in a village are aware of local conditions even to the extent of knowing what is going on in households. This is particularly true of societies where avoidance of outright indigence by sharing of resources is a custom. At the local level such knowledge might be used to provide advance warnings of the onset of severe shortages if channelled into an appropriate institutional framework.

Overall, to reduce seasonal and inter-year fluctuations in food supply, production systems have to be less risky, for both women and men. Many technical interventions increase variability and risk, especially when they depend on poorly functioning markets. Reducing the risk of adverse seasonal effects requires diversification, wider choice of crop, livestock and income-earning activity, marketing infrastructure and support, and for poor households multiple sources of food and income.

\section{Implications for Research}

Within many of the policy options mentioned above there is need for research to better define how poor people's production activities could be strengthened. In other words, seasonal coping strategies require more investigation: what are their limits (especially in the face of population growth and on marginal land)? How far are they reversible? And how might development efforts strengthen them? In allocating research resources it is now possible that less needs to be spent on describing seasonal patterns. We should use an analytical framework that builds and tests short interdisciplinary hypotheses about causal chains. These would link among other factors, particular seasonal events, random bad years and trends in the political economy. Some of the best lessons might be empirical, from implementing counterseasonal policies and seeing how seasonally vulnerable people are affected and respond. Important lessons could be learned from analysing the many famine early warning systems now being set up in dry Africa. 
Seasonal factors are not new to on-farm research and farming systems research generally, but need to be further integrated in them. Farmers have priorities for different types of crops according to their vulnerability to seasonality. They allocate their land, labour and other inputs according to these priorities. This also has implications for the sexual division of labour and control of product in the household which in turn has further seasonal implications.

Institutions also play a part in counter-seasonal strategies. Basic research on financial institutions for the management of inter-seasonal and inter-annual risk, i.e., insurance, banking, credit and redistributive taxation, might bring benefits. In particular, rotating credit associations are present in most rural communities and are a local means of saving and meeting cash needs. The effective introduction of more extensive financial networks would require an examination of the working of these local institutions. Local organisations can also be used to build institutions for management of common property resources of seasonal importance: trees, rangeland, water, fish and wildlife. Our information on such institutions is poor.

Finally, more should be known about how seasonal deprivation influences people in their attitudes to innovation, risk-taking, and planning ahead. These might be described as psycho-physiological factors. For example, is expected seasonal deprivation a factor inducing people to the strategy of having many children? Might a lower birth rate be expected where fluctuations in food supply, even for poor people, are not severe?

This selective agenda of policy and research needs show that seasonality matters especially for the poor and vulnerable, and that policies and projects can have components which reduce seasonal adversity. It is especially - though not only - in those parts of the world which are remote, semi-arid, or arid and with uncertain rainfall that seasonality has become and must remain a prominent dimension of policy and research.

\section{References}

Campbell, D. J., and D. D. Trechter, 1982, 'Strategies for coping with food consumption shortage in the Mandera Mountain Region of North Cameroon', Social Science \& Medicine 16, pp2117-27

Chambers, R., R. Longhurst and A. Pacey (eds.), 1981, Seasonal Dimensions to Rural Poverty, Frances Pinter, London

Cutler, P., 1985, The Use of Economic and Social Information in Famine Prediction and Response, Report to the Overseas Development Administration, London

Gillespie, S., 1980, 'Perceptions of health and seasonality in two South Indian tribal groups', London School of Hygiene and Tropical Medicine (mimeo) 


\section{Books Received}

El Haj Bilal Omer, The Danagla Traders of Northern Sudan, Ithaca Press, London, 1986

Zulkuf Aydin, Underdevelopment and Rural Structures in Southeastern Turkey: the household economy in Gisgis and Kalhana, Ithaca Press, London, 1986

R. S. Ganapathy et al (eds.), Public Policy and Policy Analysis in India, Sage, New Delhi and London, 1985

Donald McGranahan, Eduardo Pizarro and Claude Richard, Measurement and Analysis of Socio-economic Development, UNRISD, Geneva, 1985

Steven E. Sanderson, The Transformation of Mexican Agriculture, Princeton University Press, 1986

Edward Maltby, Waterlogged Wealth: why waste the world's wet places? Earthscan, London, 1986

Gunilla Andrae and Björn Beckman, The Wheat Trap, Zed, London, 1986

Ozay Mehmet, Development in Malaysia, Croom Helm, London, 1986

Robert Klitgaard, Data Analysis for Development, OUP, Pakistan, 1985

Ian Smillie, No Condition Permanent: pump-priming Ghana's industrial revolution, Intermediate Technology Publications, London, 1986

Arnold Pacey with Adrian Cullis, Rainwater Harvesting: the collection of rainfall and run off in rural areas, Intermediate Technology Publications, London, 1986

Review '85 Outlook'86, North-South Institute, Ottawa, 1986

Gregory J. Scott and M. Gary Costello (eds.), Commercialización Interna de los Alimentos en America Latina: Problemas, Productos y Politicas, IDRC, Ottawa, 1985

Rapid Population Change in China, 1952-1982, Report No. 27, Committee on Population and Demography, National Academy Press, Washington DC, 1984

Peter Bartelmus, Environment and Development, Allen \& Unwin, Boston (Mass.), 1986

People's Participation in Development and the Management of Natural Resources, Report on the Caribbean Regional Workshop in Vieux Fort, St. Lucia, April 15-19, 1985 , CODEL, New York, 1986
Douglas E. Horton, Social Scientists in Agricultural Research: Lessons from the Mantaro Valley Project, Peru, IDRC, Ottawa, 1984

Robert E. Rhoades, Breaking New Ground: Agricultural Anthropology, International Potato Center, Lima, 1984

Gregory J. Scott, Markets, Myths and Middlemen: a study of potato marketing in Central Peru, International Potato Center, Lima, 1985

Poverty and Hunger: Issues and Options for Food Security in Developing Countries, The World Bank, Washington DC, 1986

A 'Geneva Group', How to Run a Small Development Project, Intermediate Technology Publications, London, 1986

Val Curtis, Women and the Transport of Water, Intermediate Technology Publications, London, 1986

Hanne Christensen, Refugees and Pioneers: history and field study of a Burundian settlement in Tanzania, UNRISD, Geneva, 1985

E. Philip English, The Great Escape? An examination of North-South tourism, The North-South Institute, Ottawa, 1986

Linda Jacobs, Environmentally Sound Small-Scale Livestock Projects: guidelines for planning, CODEL/HPI/VITA/ Winrock International, New York, 1986

Stefan Musto (ed.), Endogenous Development: a Myth or a Path? Problems of Economic Self-Reliance in the European Periphery, Eadi-Book Series 5, German Development Institute, Berlin, 1985

Yearbook of Socio Economic Indicators of the OIC Member Countries, 1985, Statistical Economic and Social Research and Training Centre for Islamic Countries/Organisation of the Islamic Conference, Ankara, 1986

University of Warwick Annual Report 1984/85

The Design and Manufacture of Animal-Drawn Carts, Intermediate Technology Publications for the International Labour Office (ILO) and the United Nations Centre for Human Settlements (Habitat), London, 1986

Ruby Sandhu and Joanne Sandler, The Tech and Tools Book: a guide to technologies women are using worldwide, IT Publications, London, 1986

Barrie Evans, Understanding Natural Fibre Concrete: its application as a building material, IT Publications, London, 1986 